\title{
Digital globalization and its impact on economic and social life
}

\author{
Sorin Burlacu ${ }^{1, *}$, Mihaela Diana Oancea Negescu ${ }^{2}$, Simona Roxana Patarlageanu ${ }^{2}$, and \\ Raluca Ana Vasilescu ${ }^{3}$ \\ ${ }^{1}$ Lecturer PhD, Bucharest University of Economic Studies, Romania \\ ${ }^{2}$ Associate Professor PhD, Bucharest University of Economic Studies, Romania \\ ${ }^{3} \mathrm{PhD}$ Student, Valahia University of Targoviste, Romania
}

\begin{abstract}
Research background: While some researchers see digital globalization as a new form of globalization, others liken digitalisation to the globalization that needs to be managed and driven so that institutions and businesses can meet the challenge of digitalisation together. Digitization has encompassed all aspects of economic and social life. In increasingly fierce competition, technological advances and the challenges of science are becoming catalysts for globalization. There is research that suggests that conventional wisdom would say that globalization has stopped arguing that global trade in goods has flattened and cross-border capital flows have fallen sharply since the economic crisis of 2008. However, research shows that globalization is not reversing but enters a new phase that could be defined by a sustained increase in data and information flows. More than a decade later, the new global crisis caused by the COVID-19 pandemic is strengthening the role of information and communication technologies in both the economy and social life.

Purpose of the article: The aim of this paper is to highlight the main characteristics of digital globalization that have a major impact on current and future economic and social life.

Methods: Documentary analysis and review of the literature are the main research methods. These are doubled by a bibliographic analysis of IT tools.

Findings \& Value added: Following the documentary analysis, we identified a series of characteristics that allow us to consider that global digitalization can become the determining factor of the economy with direct implications in social life.
\end{abstract}

Keywords: digitization; globalization; IT\&C

JEL Classification: $F 01 ; F 12 ; F 15$

\footnotetext{
* Corresponding author: sburlacu@amp.ase.ro
} 


\section{Introduction}

Globalization now converges with digitalization is the idea that emerges from current research. This is because globalization can be measured in large part by trade in goods and cross-border financing and by the enormous flows of data and information that are transmitted every minute, ideas and innovations circulate around the world. Otherwise, companies should rethink what it means to be global as these vast digital networks connect everything, in any place and in any space. Such research quantifies the economic impact of this change and suggests five critical areas along with challenges such as: the new bit trade, open platforms, virtual goods and "digital packaging" or the grounding of digital dialogue (Bughin et al., 2016).

More and more recent research claims that digital globalization is a new form of globalization and that it would bring relevant changes to the way business is conducted. Digital globalization is increasing global economic, financial and social connections through digital platforms as data and information grow. More than a year after the Covid-19 pandemic, this research considers that it has caused a shock to the global economy, which is proving to be perhaps faster and more severe than the global financial crisis of 2008. If the Covid-19 pandemic is a challenge for digital globalization and the digital transformation of economies, economic research believes that the current crisis could push towards deglobalization. There is more and more discussion about the challenge that the crisis caused by the coronavirus pandemic poses to globalization and the digital transformation of economies (Schilirò, 2020).

On the other hand, we are in agreement with those researches carried out before the COVID-19 pandemic, which considered that education is the link between a constantly changing technological field and the forces of the globalization market. This research examines how the effects of education manifest in relation to the practices that underlie the socio-economic and politico-ideological conditions of teaching and learning. It is considered that the requirements of the corporate agendas that support the technological competence necessary for a new careerism have transformed the educational objectives and the ethical-political dimension of knowledge is recognized, which a technological rendering of education diminishes. (Trifonas, 2017).

There is also research that believes that growing globalization and the growth of world markets through higher exports have threatened the economic growth of developed economies that import more than exports, following the example of the United States. Thus, different countries have come to practice economic nationalism in different ways, based on their emerging priorities in social, political and economic contexts. There is currently a recent increase in economic nationalism in both developed and developing economies. It is argued that many Asian companies have become globally competitive through the use of globalization and economic nationalism. As a result, many Western nations, including the United States, are beginning to use nationalist economic policies to promote their own industries and make them more competitive globally. In short, the economic openness of a country affects its economic nationalism (Chernyshenko et al, 2020).

Both globalization and digitalization considerably influence labor and the labor market. Some research reveals the changing problems of the work safety model under the influence of globalization. Their focus is on changes in the labor market due to different technologies of employment, interpenetration and use of labor, as opposed to the usual interpretation of the impact of globalization processes. Research finds that globalization processes can 
radically change the model of work safety and propose the establishment of normative norms for work organization in non-standard employment (Mandych et al., 2018).

\section{Methods}

Documentary analysis and review of the literature are the main research methods. These are doubled by a bibliographic analysis of IT tools. The documentary analysis method was the primary research method utilised. Since these databases contain a large number of bibliographic references, the VOS viewer was selected for use in visual representation analysis in order to highlight the relationships between concepts and ideas.

VOSviewer is described as a software tool for creating and viewing bibliometric networks by the program's developers. It is also stated that bibliometric networks can include both individual journals or publications as well as individual researchers, which is an important distinction. It is possible to construct networks based on the use of quotations, bibliographic engagement, co-quotation, or co-author relationships. The text mining functionality of the software solution was taken into consideration when selecting it, as it would be used to build and visualize co-emergence networks of key topics extracted from a body of scientific literature.

\section{Results}

Following the documentary analysis, we identified a series of characteristics that allow us to consider that global digitalization can become the determining factor of the economy with direct implications in social life. These features will be summarized as follows:

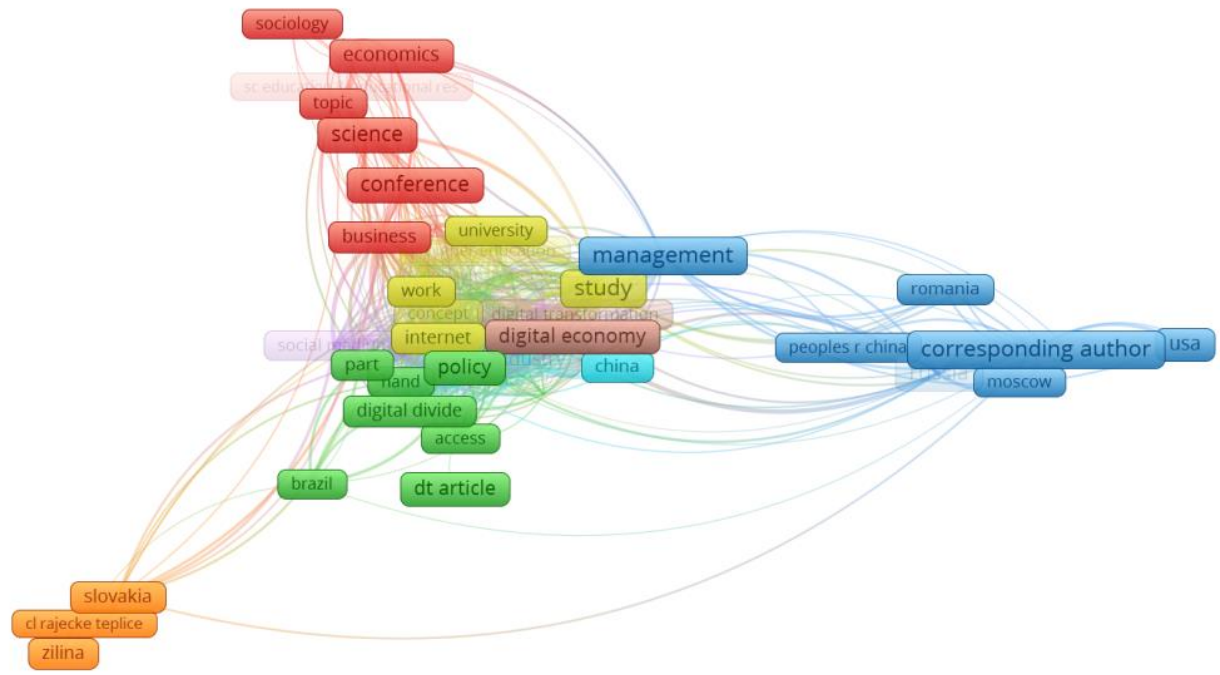

Figure 1. Map of bibliographic references.

Source: VOSviewer application with Web of Science data

From the representation highlighted in figure no, 1 we find that the relationship between digital globalization in relation to economic and social life has found a special place that determines us to investigate more closely this connection. This research gap identified in the existing literature suggests possible future directions for our further research. 


\section{Global labor force}

Recent studies show that worldwide, countries are rethinking the conditions of employment in globalization. In fact, the disruptive effects of globalization on millions of workers in the advanced economy have long been recognized. However, research recommends that new trade policies be based on a clear understanding of how globalization is evolving because this new form of digital globalization is more knowledge-intensive than capital or labor. In essence, this requires broadband connections rather than conveyor belts. The COVID-19 pandemic has made lifelong learning faster from slogan to reality. These studies recommend that mid-career retraining be made available not only to those who have lost their jobs due to foreign competition, but also to those facing disruptions in the ongoing process of automation and training programs to it can transmit new skills in a few months, not years, and can be complemented by programs that support workers' incomes during retraining and help them move to more productive work. It is clear that most advanced economies, including the US, have not adequately responded to the needs of communities and individuals left behind by globalization, so addressing these needs has now become of paramount importance (Tyson \& Lund, 2017).

Mils (2003) considers that in a diverse global economy, gender ideologies can support flexible ways of controlling and disciplining work due to their ability to naturalize arbitrary and constructed statements about whose work is worth more (or less) and what Body types are best suited for certain tasks. However, the researcher notes that global transformations in production, mobility and livelihoods have specific effects on the lives of gender subjects, creating tensions and conflicts, as well as new possibilities. Thus, the resulting struggles involve men and women, workers and employers, communities and states in contests that can sometimes reproduce existing power relations; however, they can also lead to new, potentially transformative forms of action and identity (Mills, 2003)

Three years later, Freeman wonders what impact a doubling of the global workforce could have on workers. His answer is unequivocal: wages would fall, unemployment would rise. His research continued with the assumption that if the nation's capital stock doubled at the same time, labor demand would increase proportionately and workers would maintain their economic position. However, if the global workforce is to be doubled, these workers will need more social support to advance in the economy than in previous years. His conclusion is that in 2006 the world entered a long and epoch-making transition to a single global economy and a labor market. He assumed that there would be many things to meet in the new economic world, but also many things to fear, and countries must develop new creative economic policies to ensure that workers do well in this transition and that the next few decades do not repeat the experience of the last twenty or thirty years in which almost all productivity gains have reached the pockets of a small class of the population (Freeman, 2007).

\section{Globalization of products and services}

In 2008, Sandhu presented in his dissertation the conclusion that the globalization of production would involve two processes: the globalization of production and the globalization of services. He considered that the reduction of the cost of transport and the development of communication satellites and other information and communication technologies) would have given rise to further fragmentation of production, which would have led to the transnationalization of production, so that the goods produced are well transnationalized. Thus, those goods are not products of a specific national state, but consider them as global products. The second process of globalization, that of services, would have begun in the $1980 \mathrm{~s}$. The 1980s are considered to be a decade between two recessions that would have squeezed companies' profit margins, at least in the United 
States. He considered that this phase of globalization lagged behind the globalization of production, because services were much more deeply embedded in the economy and culture than was production. Thus, it notes that while the recession of the early $1980 \mathrm{~s}$ was a recession with a blue collar, the recession of the end of the decade was a recession with a white collar and the pressure to further reduce labor costs combined with the new information technology introduced. led to a reorganization of companies that began in the late 1980s and deepened in the 1990s. One prediction would be that the globalization of services could expand while the globalization of production would slow as transport costs increase. Suppose that because the globalization of services will require less energy costs, they may be more likely to survive and expand and that virtual network connections that have been established under the oceans could actually become conduits for more information and data, as a more and more work will become virtualized. It suggests that it makes more sense to have virtualized information and data moved, than to move people and goods, which would be more energy efficient (Sandhu, 2008).

\section{Economic and social globalization}

A recent study found that many developing countries have tried to accelerate their economic growth, following outward-looking policies aimed at integration into the world economy. If most investigations related to economic growth have approached this topic from the perspective of physical capital, human capital, natural resources and technological knowledge. this study focused on globalization and its impact on economic growth. The aim of this study was to investigate whether economic, social and political globalization had an impact on economic growth within ASEAN (The Association of Southeast Asian Nations) between 1970 and 2008.

The study concluded that economic globalization has a positive influence on economic growth, while social and political globalization has negative effects. In other words, economic globalization is proving to be more effective than political or social globalization in stimulating economic growth. The researchers' recommendation would be for governments to be more active in promoting international trade and foreign investment and to pay particular attention to the negative impact of political and social globalization on economic growth (Ying et al., 2014).

\section{Globalization and decentralization}

Currently, researchers find that globalization and decentralization are probably the most important sources of transformation of the nation-state in recent decades. They believe that power has migrated from central governments upwards, with the creation of international organizations and economic integration, but also downwards, with the global transfer of decision-making powers to regional and local governments. He also considered that these two processes took place simultaneously even though the study of the literature has not yet provided a clear presentation of how they are linked. In their attempt to shed light on the relationship between the two, considered to be one of the most important processes in world politics in the last four decades, they conclude that states have become increasingly integrated into global markets, and have allowed power to either migrate. to international organizations, or simply be limited by international economic dynamics, with many countries shifting power down and increasing the fiscal authority of regional governments. Their research suggests that globalization and decentralization are more than two simultaneous processes taking place in the same period, being two positively correlated dynamic processes (Jurado and León, 2021). 


\section{Discussion - Globalization and the outbreak of the COVID-19 pandemic}

Research by Farzanegan and his collaborators during the COVID-19 pandemic finds that while globalization has a favorable impact on growth and employment, the effect of the health crisis would reveal its dark side. Researchers recommend that policy makers take into account the health risks associated with the growing trend of globalization of markets and societies as the growing trend of globalization and opening of trade borders in countries with low quality formal institutions and monitoring capacity, associated with low transparency of information and government accountability can lead to illicit trade and smuggling. The idea is argued that there are types of trade that are part of the hidden economy and that due to their hidden nature, it is even more difficult to control in terms of diseases. The researchers believe there is ample evidence that COVID-19 was first identified at a seafood market in Wuhan, where wild animals such as marmots, birds, rabbits, bats and snakes were traded illegally, recalling situations. relatively similar in previous contagions, such as Ebola viruses and SARs. The existence of large, unhealthy and poorly regulated illicit markets in each of these cases would have provided an ideal environment for disease and globalization combined with the poor quality of institutions would have amplified the speed of these outbreaks (Farzanegan et al., 2021).

\section{Conclusion}

The digitalization of globalization is imminent (Burlacu et al., 2021), if it has not already happened as a result of more than a year of global measures based mainly on employment and online school to maintain social distance as a basic measure in combating the Covid-19 pandemic (Balu et al., 2021). Its economic impact could be measured both in monetary units and in the volume of trade or labor (Radulescu et al., 2021). Its social or life impact can also be easily understood both in the short and long term (Sarbu et al., 2021). Replacing direct communication with distance communication that drastically limits emotional transmission may be factors that shape these horizons. However, more in-depth research is needed to differentiate between what is considered beneficial and what could be harmful, today or in the future. The proliferation of technologies was possible due to scientific progress but perhaps also to the enthusiasm with which these advances were received. Meanwhile, digitalization has become so complex but also uniform at the same time, from cloud computing, smartphones, massive data, digital mining, cryptocurrencies or artificial intelligence that it is possible to meet all this in one place and everywhere. Concerns about the digitalization of globalization remain today on the front page of researchers around the world.

\section{References}

1. Balu, F. O., Radulescu, C. V., Bodislav, D. A., Gole, I., Buzoianu, O. C. A., Burlacu, S., \& Balu, P. E. (2021). Cost modeling and computation in the healthcare industry. case study on a swiss medical care organization. Economic Computation \& Economic Cybernetics Studies \& Research, 55(1).

2. Bughin, J., Lund, S., \& Manyika, J. (2016). Five priorities for competing in an era of digital globalization. McKinsey Quarterly, 2, 55-61. 
3. Burlacu, S., Diaconu, A., Balu, E. P., \& Gole, I. (2021). The economic and social effects of unemployment in Romania. Revista de Management Comparat International, 22(1), 21-27.

4. Burlacu, S., Patarlageanu, S. R., Diaconu, A., \& Ciobanu, G. (2021). E-government in the era of globalization and the health crisis caused by the covid-19 pandemic, between standards and innovation. Les Ulis: EDP Sciences.

5. Chernyshenko, V., Vertakova, Y., \& Mkrttchian, V. (2020). Development and Implementation of Adaptive Trade Policy in the Era of Digital Globalization Based on Virtual Exchange of Intellectual Knowledge. In V. Mkrttchian, L. Gamidullaeva, \& E. Aleshina (Ed.), Avatar-Based Models, Tools, and Innovation in the Digital Economy (pp. 131-140).

6. Farzanegan, M. R., Feizi, M., \& Gholipour, H. F. (2021). Globalization and the outbreak of COVID-19: An empirical analysis. Journal of Risk and Financial Management, 14(3), 105.

7. Freeman, R. (2007). The great doubling: The challenge of the new global labor market. Ending Poverty in America: How to Restore the American Dream, August, $55-65$. http://emlab.berkeley.edu/users/webfac/eichengreen/e183_sp07/great_doub.pdf.

8. Jurado, I., \& León, S. (2021). Economic globalization and decentralization: A centrifugal or centripetal relationship? Governance, 34(3), 665-686. https://doi.org/10.1111/gove.12496

9. Mandych, O., Kalinichenko, S., Duyunova, T., Sekovoy, O., \& Mykytas, A. (2018). Fundamental and applied researches in practice of leading scientific schools Competitive development of subjects of the agri-business: Theory and practice. 28(4), 86-91.

10. Mills, M. B. (2003). Gender and inequality in the global labor force. Annual Review of Anthropology, 32, 41-62.

11. Rădulescu, C. V., Burlacu, S., Bodislav, D. A., \& Bran, F. (2020). Entrepreneurial education in the context of the imperative development of sustainable business. European Journal of Sustainable Development, 9(4), 93-93.

12. Radulescu, C. V., Ladaru, G.-R., Burlacu, S., Constantin, F., Ioanăș, C., \& Petre, I. L. (2021). Impact of the COVID-19 pandemic on the romanian labor market. Sustainability, 13, 271.

13. Sandhu, A. S. (2008). Globalization of Services and the Making of a New Global Labor Force in India's Silicon Valley. University of California Santa Barbara, May, $2-4$.

14. Sarbu, R., Alpopi, C., Burlacu, S., \& Diaconu, S. (2021). Sustainable urban development in the context of globalization and the health crisis caused by the covid19 pandemic. Les Ulis: EDP Sciences.

15. Schilirò, D. (2020). Towards digital globalization and the covid-19 challenge. International Journal of Business Management and Economic Research, 2(11), 1710 1716.

16. Trifonas P. (2017). Digital globalization and the ends of education. In: Heidkamp B., Kergel D. (eds) Precarity within the Digital Age. Prekarisierung und soziale Entkopplung - transdisziplinäre Studien. Springer VS, Wiesbaden.

17. Tyson, L., \& Lund, S. (2017). Adapting to the new globalization. Project Sindicate. 
18. Ying, Y. H., Chang, K., \& Lee, C. H. (2014). The impact of globalization on economic growth. Romanian Journal of Economic Forecasting, 17(2), 25-34. 